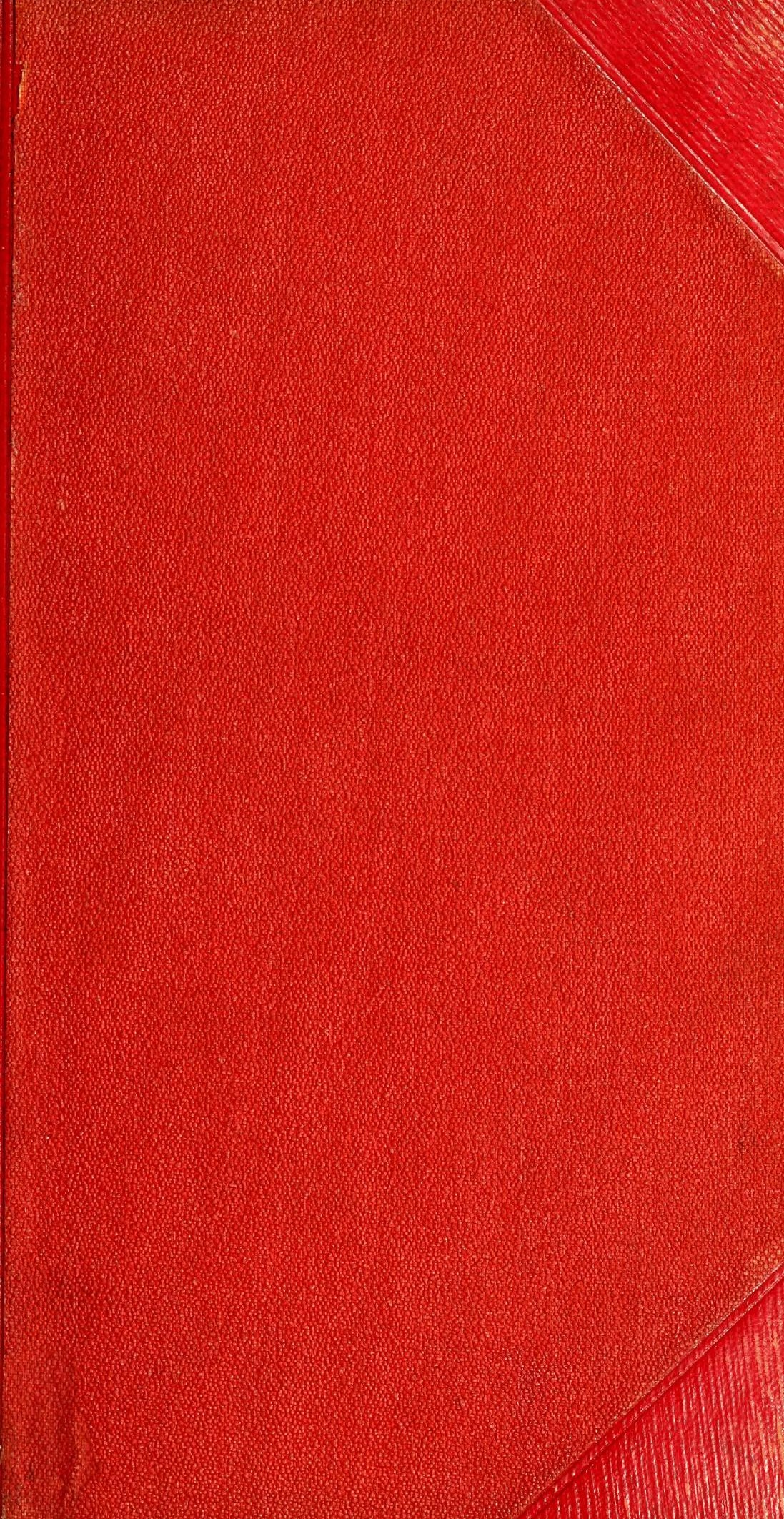




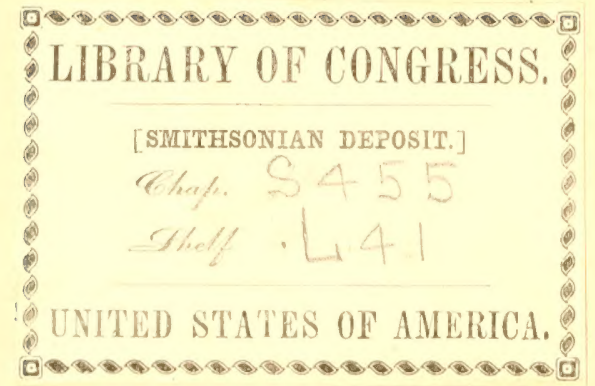








\section{IS HIGHER FARIING A REMEDY FOR}

\section{LOWER PRICES ?}

BEING THE SUBSTANCE OF A LECTURE DELIVERED BEFORE THE EAST BERWICKSHIRE AGRICULTURAL ASSOCIATION, ON SATURDAY, MAY 3, IS79.

BY

JOHN BENNET LAWES, LL.D., F.R.S., \&c., OF ROTHAMSTED, HEITS.

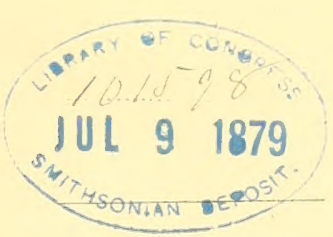

BERWICK-UPON-TWEED :

PUBLISHED BY G. MACASKIE, "WARDER" OFFICE, 1879. 


$$
5+5^{5}
$$




\section{IS HIGHER FARMING A REMEDY FOR LOWER PRICES?}

There can be no doubt in the minds of all present that British Agriculture is passing through a erisis of unusual severity. The complaints which farmers are accused of making, even in the best of times, spring from very different causes from those which we now hear of around us. Bad seasons, following each other in close succession, in a manner quite unusual even in the uncertain climate of these islands, have seriously reduced the produce of the land. Immense importations of corn have deprived the farmer of the higher prices which would otherwise have compensated him for his diminished crops. He pays a higher price for labour, frequently without any corresponding increase in its efficiency. Lastly, diseases among stock, the dread of future disease from imported animals, and the influence of importations of live stock and dead meat upon prices, present and prospective, have greatly increased his difficulties. For the moment his energies are paralysed, and he is led to inquire what he is to do next?

It need hardly be said that, under these circumstances, advice is not wanting. In fact, it is so abundantly offered, and is of such various kinds, that you must have some difficulty in selecting that which is most applicable to your own case. You are told to farm more scientifically, to meet lower prices by increased production, or to put a stop to music in your family circle! These are specimens of the numerous remedies proposed to enable you to meet the difficulties which at present surround you, and still to carry on your farming operations with a profit. 
It will doubtless be some comfort to you, if I say at the commencement of my address, that I do not propose to add myself to the list of your advisers. I possess no specific against the combined effects of bad seasons, cheap corn, dear labour, and cheapening meat. You will gather from the title of my paper that my object is rather to assist you in examining into the applicability of one of the pieces of advice frequently offered to you; namely, that you should meet lower prices by increased production.

No one will deny that a great deal of the land of the country is badly farmed, or that it would be more profitable to raise more produce upon it. To what extent such is the case in Berwickshire I am unable to say. A reference to the Agricultural Statisties will, however, give us some idea of the general character of the cultivation of the county. I find that, in 1878, it comprised 193,622 acres of arable and pasture land, exclusive of heath or mountain land, and that this area was under different crops, as follows :-

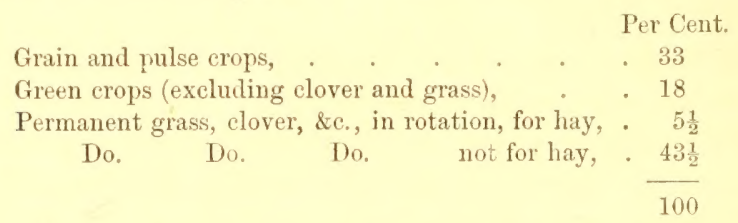

Thus, scarcely one-third is devoted to the growth of corn crops; and even if all the corn and potatoes grown, and all the hay made, were sold off the farm, the produce of scarcely 40 acres in every 100 would be sold, leaving 60 for consumption by stock for the production of meat and manure, the latter to be retained on the land. But we know how wide of the truth it is to assume that all the hay and oats grown are sold; and we have at the same time to bear in mind, that the straw grown on the 33 per cent. of land which is devoted to corn, will for the most part be retained on the farm. If, in addition to these facts, we were to take into account the cattle foods and manures purchased and brought on to the land, I think we should have abundant evidence that Berwickshire is, upon the whole, a highly farmed county; and if a certain proportion is badly farmed, we may conclude that the remainder is in a high state of cultivation. 
It is to those in this county who do already farm highly that my remarks are chiefly applicable; but they will apply also to high farming generally, wherever it may be practised. No one, I suppose, can doubt that the soils of this country are capalle of producing very much more wheat and meat than they do at present, if not, indeed, all that is required to support the population. If imports of these articles were prohibited, or a heavy duty imposed upon them, there is no doubt that a much higher system of farming would be profitable than at present prevails. In such a case, however, our dependence on the produce of foreign soils would not be lessened. The increased production of wheat and meat here supposed conlel only be attinined by increased imports of cattle foods and manures. The countries which now supply us with wheat and meat would supply instead such products as they were permitted to sell to us. Our dependence on the foreigner would therefore be equally great; the only difference wonld he that it would be for other commodities than at present.

Our subject is not, however, what shonld be done if wheat and meat were to advance in price; but whether a higher standard of farming can be recommended to compensate for a reduction in price. To put the matter plainly:-supposing there were a jermanent reduction in the price of the salealle produce of the farm to the extent of 20 per cent., would the proper remedy be to increase our produce per acre by onefourth, and so to bring up the saleable value to the same amount as before?

There can be but little difference of opinion as to what is to be understood by the term "high farming." It is certainly not high farming that produces the wheat which is now selling at so low a price in our markets. When we read in the United States papers that in one year 20,000,000 acres of lind had been purchased for cultivation, and that within ten years $10,000,000$ acres had been added to the area under wheat alone, it will be at once understood that it is what is called retensive as distinguisher from intensire, or high farming, that has yielded the supplies we receive. Nor can there be any doubt as to one main canse at least, of the present depression. Farming on the four-course system, consuming 
cach alternate crop on the farm, and, in addition to this, converting all the straw of the corn crops into manure, but without the use of purchased foods or manures, would not constitute high farming.

High farming is a very different process. It implies the importation of material from without. All soils are capable of yielding more or less annually from their own substance to the produce which grows upon them. But, the greater the amount of cattle-food and manure purchased and brought upon the land-that is, the higher the farming-the less will the soil itself contribute to the crops. Indeed, in many cases, it contributes nothing at all, but becomes richer by the process. Under such circumstances, the soil may be said to serve mainly as a reservoir for the manures applied, and for the necessary moisture, and to afford support to the growing plants; so that, with the aid of the sun's rays, they may be enabled to accumulate carbon (and other constituents) from the atmosphere. They thus, so to speak, manufacture raw material supplied from external sources. Under such conditions agriculture is a manufacture depending on the products of other soils, and on the atmosphere, for its raw material, just as much as do the manufactures of wool, cotton, and silk depend on external sources for their material.

Adopting the foregoing description of high farming, we have next to inquire whether those who already practise it should carry it out still further, as a means of compensation for a lower standard of prices of corn and meat?

Before any answer can be given to this question, it will be necessary carefully to consider what are the various somces, the effects, and the cost of manures.

Many of the charges connected with farming are much the same whatever may be the value of the crops grown. Of course, harvesting a large crop of corn costs something more for labour than harvesting a small one, and the expenses on a heavy crop of roots will also be somewhat more than on a light one. Still, it may he said that, with the exception of the extra cost of the manure required to grow the larger crop, the charges remain very much the same whether the amount, and the value, of the produce be great or small. If, therefore, the increase in the produce bore a constant proportion to the 
increase in the amount, and consequently the cost, of the manure applied-if, in fact, the application of two or three times as much manure yielded twice or thrice as much increase of crop-then higher farming would be a remedy for lower prices. But such is not the case. It may, it is true, be said that, as the produce increases, the proportion of the fixed expenses to be charged upon a given amount of it diminishes, thus tending to compensate for the less productiveness of a given amount of manure the greater the quantity of it applied. But a very little consideration of the facts I propose to bring before you would show that, with increased production beyond a certain limit, the cost of the manme for a given amount of increase increases very much more rapidly than the proportion of the fixed expenses diminishes.

Nowhere are the extremes of farming better illustrated, and nowhere can they be better studied, than in the results of the field experiments at Pothansted. Nowhere else are various crops grown for a great many years in succession, in some cases without any manure at all, so as to tax the capability of the soil itself to the utmost, and in others with very liberal supplies, either of farmyard manure or of artificial manures, so as to enrich it as much as possible. So liberal, indeed, has been the application of farmyard manure in some of the experiments, that a critic, who apparently did not quite understand their object, was reported in the North British Agriculturist to have said that we seemed to have a spite against farmyard manure, as he considered that much smaller applications would have produced as much effect.

I propose now to call your attention to some of the field experiments in question, the results of which will prove that, beyond a certain limit, the increase of crop is not in proportion to the increase in the amount of manure applied. In other words, that the higher you farm beyond a certain limit, the less is the amount of increase you obtain for a given amount of manure, and, therefore, the greater the cost of that increase. If this be the case, it is obvious that the cost of manure is a very important subject for consideration.

It is frequently assumed that the manure made by feeding stock costs nothing; that by skilful and judicious management, the cost of the food, and the other expenses, will be 
covered by the value of the meat produced and sold; and that, this being so, the manure is obtained gratis. I shall, therefore, occupy a portion of the time at my disposal in illustration of the fact that the food of an animal will, as a rule, cost more than the meat produced will sell for; and that, conserquently, the cost of the ford, and the other necessary expenses, can only be recovered by charging a portion to the manure.

To commence with the field experiments. I shall first call your attention to some of the results of some experiments on an ordinary rotation of crops, which are now in the thirtysecond year of their progress. The arrangement of them is in reality very simple; though, from their number, it will require a little attention fully to comprehend the plan.

\section{Experiments on Rotation.}

The ordinary four-course rotation of turnips, barley, clover or beans, and wheat, has been adopted; and the eighth crop of wheat, that is to say, the last crop of the eighth course, is now growing. In the first course, a large crop of clover, which was mown three times, was obtained. In the second and third courses, red clover was again sown, but it failed anch time, and beans were then put in instead. Beans were also grown in the fourth, fifth, sixth, and eighth courses; hut in the seventh, red clover was again trjed, and it grew s'tccessfully, again yielding three cuttings. We have had, therefore, eight crops of roots, eight of barley, six of beans, two of red clover, and seven of whent; the eighth of this last crop being now growing.

Such being the course of cropping, I will now explain the system adopted as to manure.

One-third of the land has been kept entirely without manure throughout the whole period of the experiments.

One-third has received mineral superphosphate of lime alone, every fourth year, that is for the root crops.

The other third has received, also every fourth year only, that is for the roots commencing each course, a very liberal artificial mixture, composed as follows: ${ }^{1}$ -

\footnotetext{
${ }^{1}$ For the first course, only 1000 lbs. rape eake instead of 2000 lbs, as always afterwards, were applied. In the first and second courses less superphosphate, and in the first course less potass, and no soda or magnesia, was used.
} 


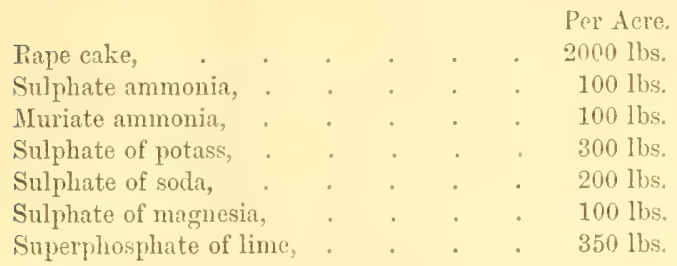

This mixture I shall speak of as the Complex Manure.

Next as to the treatment of the crops:-

Each of the three portions, so differently treated as to manure, has been divided into two experiments. From one half, the whole of the produce, roots and tops, corn and straw, and clover, has been removed. On the other half of each, the only difference has been, that the roots were fed on the land hy sheep having no other food, and the tops were also left on the land.

We have, therefore, three experiments in which the whole of the produce has been carried away for thirty-one years in succession; on one without any manure having been applied; on another with mineral supresphosphate of lime alone, applies to the roots, that is every fourth year; and on the third with a very heavy artificial manuring, also for the roots only. We have also three exactly parallel experiments with the roots fed upon the land by sheep instead of being carted away.

I may mention that there is another series of six experiments, corresponding in every respect with those the results of which are given in the Tables, with the exception that bare fallow, instead of either beans or clover, has been taken between the barley and the whent in each course since the first, when clover was taken. I do not propose to refer to this last set of experiments on the present occasion, as to do so would lead me away from my subject; but I may observe that the comparison between a rotation with clover or beans, and one with bare fallow, presents many points of interest.

I will now call attention to the results obtained in these Rotation Experiments. In Table I. is given the produce of roots, of corn, and of clover hay, and to this I shall confine my remarks. But, for the information of those who may wish to study the subject further, there are given in Table II. the amounts of the "Swede-tops" and of the straw also. 
TABLE I.

Experiments on Four-course Rotation, at Rothamsted.

Summary:-Average Produce of Roots, Com, and Clover Hay; Eight Courses, 1848-1879.

Roots-Srvedes, 7 crops ; 1848, 1852, 1856, 1860, 1861 , (1868 failed), $1872,1876$.

Unmanured, continuously,

Superphosphate, for Roots only, . . . .

Complex Manure, for Roots only,

Barley Giain, 8 crops ; 1849, 1853, 1857, 1861, $1865,1869,1873,1877$.

Unmanured, continuously,

Superphosphate, for Roots only, . . . .

Complex Manure, for Roots only,. . .

Bcan Conn, 6 erops ; 1854, 1858, 1862, 1866 , $1870,1878$.

Ummanured, continuously, .

Superphosphate, for Roots only, .

Complex Manure, for Roots only, .

Clover, 1850 and 1874. (Calculated as Hay.)

Unmanured, continuously, $\left\{\begin{array}{c}1850, \\ 1874, \\ \text { Mean. }\end{array}\right.$

Superphosphate, for Roots only, $\left\{\begin{array}{l}1850, \\ 1874,\end{array}\right.$ ( Mean,

Complex Manure, for Roots only, $\left\{\begin{array}{r}1850, \\ 1874, \\ \text { Mean, }\end{array}\right.$

Bushels. $\quad$ Bushels. $12 \frac{1}{8}$

$12 \frac{1}{8}$

Roots

Carted. Fed.

Bushels.

Bushels. 35

$28 \frac{1}{4}$ $41 \frac{5}{8}$

$30 \frac{7}{8}$

$39 \frac{7}{8}$

$46 \frac{7}{8}$

$21 \frac{7}{8}$

12

$14 \frac{8}{4}$

$24 \frac{5}{4}$

\begin{tabular}{|c|c} 
Cwts. & Cwts. \\
54 & $49 \frac{5}{8}$ \\
$31 \frac{3}{4}$ & 28 \\
\hline $42 \frac{7}{8}$ & $38 \frac{3}{4}$
\end{tabular}

\begin{tabular}{|l|l}
$57 \frac{3}{4}$ & $51 \frac{1}{2}$ \\
$52 \frac{1}{8}$ & $62 \frac{3}{4}$ \\
\hline 55 & $57 \frac{1}{5}$
\end{tabular}

Whect Grain, 7 crops ; 1851, 1855, 1859, 1863, $1867,1871,1876$.

Ummanured, continuously, .

Superphosphate, for Roots only, .

Complex Manure, for Roots only, .

- $\left|\frac{63}{84_{4}^{1}} \cdot \frac{82_{8}^{3}}{73_{8}^{5}}\right| \frac{745}{74}$

Bushels. | Busliels. \begin{tabular}{l|l}
30 & 26
\end{tabular} $29 \frac{1}{4} \quad 32 \frac{1}{2}$ $32 \frac{1}{2}$
$33 \frac{1}{4}$ 


\section{TABLE II.}

Experments on Four-course Rotation, at Rothamsted.

Summary:-Average Produce of Swede-Tops and of Straw; Eight Courses, 1848-1879.

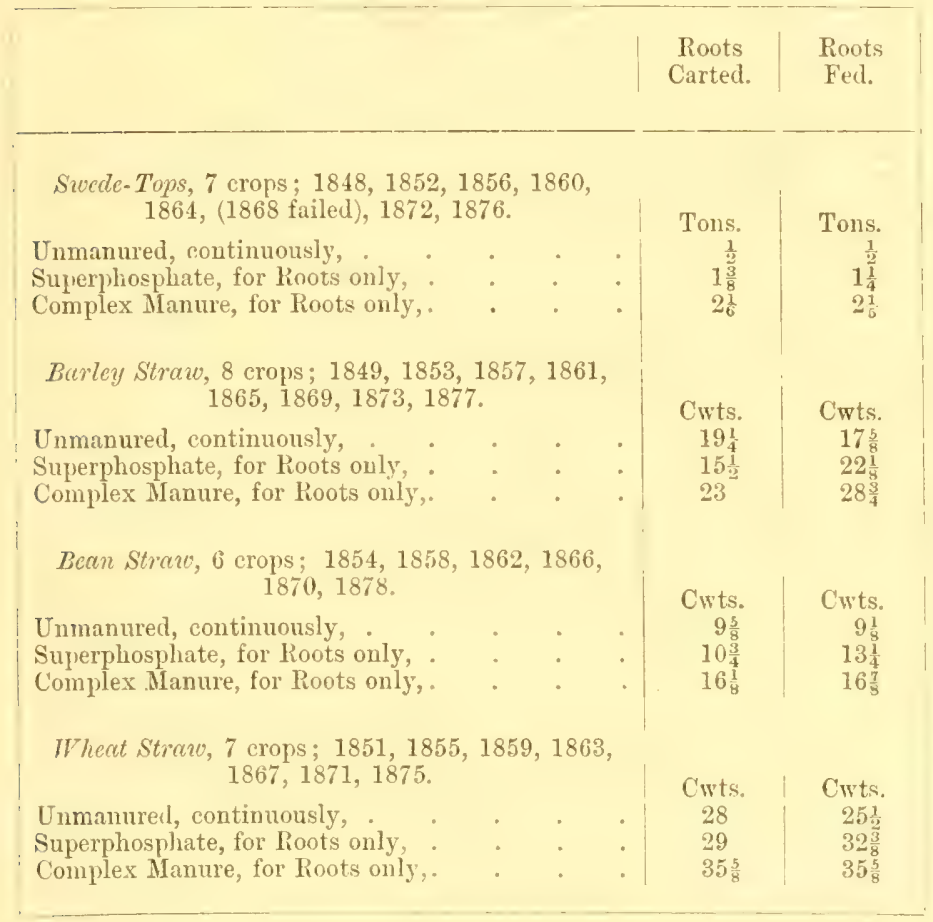

In the upper division of Table I. you have the average produce of roots per course, over seven courses (one failing), under each of the three conditions as to manure, and both on the carted and on the fed portions of the land. You will observe that, withont manure, there was practically no crop of roots at all. The swedes which grew did not represent the cultivated root you are accustomed to see, either in size, form, or composition. Mineral superphosphate of lime, alone, increased the crop considerally, giving an average of between 7 and 8 tons of roots. The complex manure gave an average of 
alout 5 tons more, raising the crop to about 13 tons. You will observe that, under neither condition as to manuring was there any material difference in the succeeding crop of roots grown on the portion from which they had previously been carted, as compared with that on which they had always been fed. It is to be concluded, therefore, that the manure left on the land by the sheep, was either taken up by the intermediate crops, lost by drainage, or remained in the land in a condition not available for the next crop of roots.

There being practically no crop of roots to carry away from the ummanured land, and as little to be fed on the land, we should naturally expect scarcely any difference in the amounts of the crops subsequently grown on the two portions of unmanured land. We find, however, a considerable difference, there being an average of more than 4 bushels of barley in favour of the portion from which the roots were carted, as compared with that on which they were fed. It is quite certain that this anomalous result is not due to any want of care in the conduct of the experiments. It may, I think, safely be attributed to a slight but unfortunate difference in the character of the land. In the present state of our knowledge on such suljects, considerable caution is necessary in attempting to trace a counection between the fertility of a soil and its composition as shown by analysis. Still, 1 may mention that, at two periods, with an interval of seven years between, samples of the lirst 9 inches, the second 9 inches, and the third 9 inches, or to a total depth of 27 inches, have been taken from each of the separate plots of land; and, on each occasion, analysis has shown a marked superiority in the land from which the roots are carted, and which has yielded the largest crops of both barley and wheat; and the superiority is the more marked in the second and third than in the top 9 inches of scill.

You will doubtless notice with some surprise that so much barley was grown on land in a condition incapable of growing even a modernte crop of roots. From 4 to $4 \frac{1}{2}$ quarters of barley is probably as much as the average yield of that crop in Great Britain. On this point it should be borne in mind, that as nothing was removed in the preceding root crop, the lind was, to all intents and purpuses, fallowed for the barley. 
It will be seen, further on, however, that the wheat crop growing in this permanently unmanured rotation, also approached very closely to the average yicld of that crop over the country at large.

Upon the land manured with mineral superphosphate for the Swedes, the removal of about 8 tons of roots (and the tops) has reduced the produce of barley to $28 \frac{1}{4}$ bushels, or to nearly 3 bushels less than the lowest ummanured produce; whilst the consumption of the Swedes on the land has raised the produce to nearly 40 bushels. The exhaustion of the soil by the removal of the roots is thus equal to the loss of more than $11 \frac{1}{2}$ bushels of barley.

Turning to the complex manure plots, it will be seen that, although from the portion from which the roots were carted a much larger quantity was removed than from the correspondiug portion of the superphosphate plots, still the crop of hatey was very much greater. It was, in fact, about $13 \frac{1}{2}$ bushels more than where the superphosphate roots were removed, and even from 1 to 2 bushels more than where the superphosphate roots were consumed upon the land.

The explanation of this is not far to seek. The superphosphate supplied no nitrogen, but it enabled the root crop to gather up a quantity already accumulated within the soil itself. The available stock within the soil of this important substance was so far drawn upon by the removal of the 8 tons of roots, and their tops, that the succeeding crop of barley was much reduced. In the rape-cake and ammonia salts of the complex manure, on the other hand, from 130 to 140 lbs. of nitrogen were supplied, and this is very much more than was removed in the 13 tons of roots grown by it. There was, therefore, a considerable residue of that supplied in the manume available for the succeeding barley crop, which was, accordingly, raised to $41 \frac{1}{2}$ bushels.

The consumption on the land of the Swedes grown by the complex manure has added only about $5 \frac{1}{4}$ bushels more. Nevertheless, it is certain that by far the larger proportion of the nitrogen, and other constituents, derived from the soil by a crop of roots, is returned to it when they are consumed by animals on the land; whilst, of those constituents which are derived by the plant from the atmo- 
splhere, by far the larger proportion is returned to the atmosphere by the animals.

It is obvious that, in this experiment, where the highly manured roots were fed on the land, compared with that where they were drawn off', we have, so far as the succeeding barley is concerned, an instance of high farming, without a corresponding return in the amount of produce.

Turning to the bean crops, it will be observed that, both on the unmanured and the siperphosphate plots, they are very small. On the unmanured plots there is practically no difference between where the roots had been carted and where they had been fed. On the superphosphate plot the crop of beans was rather higher where the roots had been fed. On the complex manure plots the crop of beans was considerably higher; being about 22 hushels where the roots hard been carted, and about $24 \frac{1}{2}$ bushels where they had been fed. This is rather more than doulle the amount obtained without manure. The difference, or 12 bushels, is, therefore, due to the residue of the manures left after the removal of the barley.

The difference in the amounts of produce of the two crops of clover is exceedingly interesting. Jietween 18.50 , when the first, and 1874, when the second crop of clover was taken, six crops of wheat, six crops of barley, and five crops of beans had been removed from the whole of the plots, and from one-half of them five crops of roots in addition.

On the unmanured plots about 1 ton less hay was grown per acre in 1874 than 24 years previously. On the superphosphate plots the second clover crop was slightly lower than the first where the roots (as well as all the other intermediate crops) had been removed; but it was in a greater degree higher where the roots had been consumed on the land. It is remarkable that, although the intermediate crops removed considerably more nitrogen, and also more of other constituents, from the superphosphate than from the ummanured plots, the superphosphate plots should still yield a much higher crop of clover at the second period. I am disposed to think that this is due, in part at least, to the gypsum contained in the superphosphate, but probably partly also to the reactions of the superphosphate in liberating other constituents within the soil. 
On the complex manure plots the clover crop of the first conrse was considerahly higher than that on either of the other plots, and the later crop, that of 1874, was about 1 ton more than the earlier one, on both the carted and the fed portions. Comparing the highest crop with the complex mamure with the lowest without manure, there is a difference of nearly 3 tons more clover hay where the land was in the much higher condition. Since the commencement of the experiments there had been seven, and since the previous clover crop in 1850 there had been six, applications of the complex manure; and althongh a large proportion of the nitrogen supplied in it is accounted for in the increase of produce removed, a large amount still remained unaccounted for. It is seen, therefore, that an important effect of the red clover is to gather up the residue of manure which none of the other crops in the rotation had been able to do. It is considered a great desideratum to grow red clover as frequently as possible; but it is obvious that the crops must be small, or fail altogether, if it be attempted to grow it when there is not a sufficient accumulated resiche of the proper matnurial constituents available within the soil.

In the lowest division of the Table the avernge produce of the seven wheat crops is given. You will observe that there is exactly the same difference between the produce of the two unmanured portions as in the case of the barley, namely, $t$ hushels; and that the lowest amount is again where the roots were fed on the land. This result affords further confirmation of the supposition that there was a difference in the character of the soil of the two plots. The average produce of the two ummanured plots is 28 bushels of wheat, and it was 33 bushels of barley. Thus, we have the remarkable fact, as already alluded to, that upon land entirely unmanured for 31 years the crops of barley and of wheat grown in the rotation have very nearly corresponded with the average yield of those crops in the United Kingdom.

The crops of wheat on the superphosphate and on the complex manure plots do not differ very much. They are higher where the superphosphate roots were fed than where they were carted; and they are rather higher still on both the complex manure plots, but identical on the two plots so manured, from 
one of which the roots were carted, whilst on the other they were fed.

I think you will agree with me in thinking that the result of this high farming, where the highly manured roots were fed upon the land, is somewhat disappointing; and that to farm still higher, as prices fall, would be a mistake.

I have long ago satisfied myself that the four-course rotation, and the feeding of roots upon the land, or even the growth of turnips at all, is quite unsuitable on the soil and with the climate of Rothamsted. We have learnt much respecting the action of manures, the requirements of different crops, and the influence of climate upon them, duriug the many years of the progress of our field experiments, and among other things, that we can gather up much more of the manure applied, by means of a mangold than of a turiep crop.

\section{Liperiments with Fumyurd Bunure.}

I will now bring before you some experiments in which farm-yard manure has been applied many years in succession to different crops. When you are urged to farm higher, the meaning is that you should put more dung upon your land. Consequently, it is of great importance to ascertain, with as much accuracy as possible, the effects of the application of linge quantities of dung.

In Table III. is given the produce of wheat, grain and straw, and of barley, grain and straw, by the application of 14 tons of farmyard manure per acre per annum. In the upper division of the Table the results obtained with wheat, and in the lower those obtained with barley, are recorded. The experiments on wheat have now been continued for 35 years, and the average produce per acre per annum is given for the first 8 years, the next 9 years, the next 9 years, and the last 9 years. The experiments on barley have been continued for 27 years, and the results are given for the three periods of 9 years each, corresponding with the last three periods in the ense of the whent. 


\section{TABLE III.}

PRODUCE OI WHEAT AND OF BARLEY, BY 14 TONS FARAYARD

MANURE PLR ACRE, EVERY YEAR.

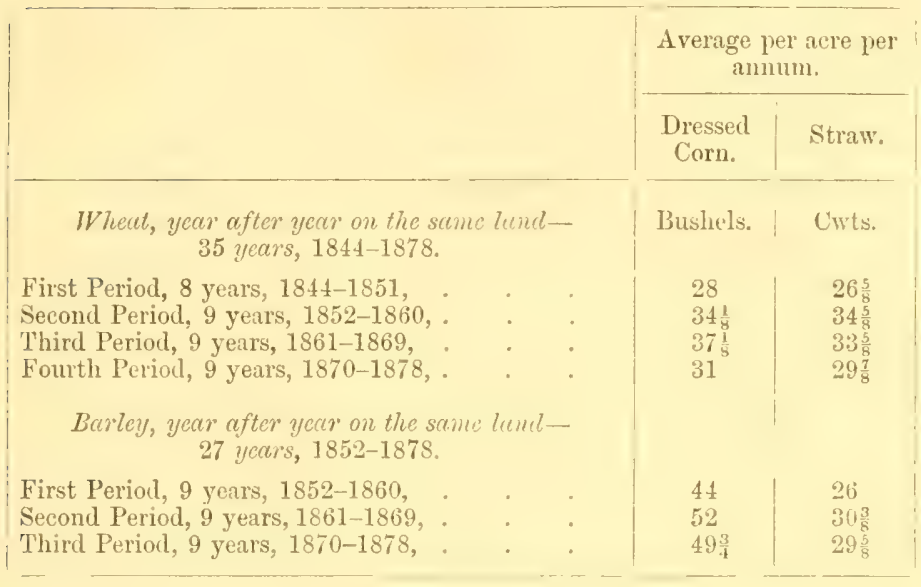

Referring first to the wheat, you will observe that the average produce of the first 8 years is the lowest, that of the next 9 years is higher, that of the third period is ligher still, and that of the last 9 years again considerably lower; being only about 3 bushels more than over the first period, about:" bushels less than over the second, and 6 brishels less than over the third period.

It is quite obvious from this result, that the produce was not at all in proportion to the accunulation of manne in the land. When the soil was analysed a few years ago, it was found that the first 9 inches in depth was nearly twice as rich in nitrogen as that of any of the artifically manured plots, yielding as much, or even more, produce. There can be no doubt that, whilst there is a general tendency to increase in produce as the result of this great accunulation of manure in the soil, the fluctuations are greatly dependent on the characters of the seasons. Thus, the third period, which gives the highest produce, included some very productive years, whilst the fourth period included a number of lad seasons, the adverse influence of which, the constantly increasing 
accumulation of manure within the soil only very partially obviated. It will be observed, too, that the amount of straw, the excess of which is a sure sign of excess of manure and over luxuriance, upon the whole increases rather less than that of the corn; there being less straw over the third period, with the highest produce of corn, than over the second with a lower produce of corn; whilst the fourth period gives considerably less than either the second or the third. This is the more remarkable, since the annual application of 14 tons of dung will have annually brought upon the land the equivalent of from 3 to 4 tons of straw. The fluctuations in the produce of straw, as well as in that of the corn, further illustrate the influence of season in spite of the accumulation of manure.

Turning to the experiments with barley, we have, upon the whole, very accordant results over the three periods, compared with the same three periods with wheat. Thus, the last period but one, which included a number of very good seasons, gave more produce than the last period, notwithstanding the greater accumulation of manure in the later years. There is in the barley, too, as with the wheat, no striking increase in the production of straw; for although there was considerahle variation in the proportion of corn to straw in individual years, according to season, the average proportion is almost identical for each of the three periods.

It is then obvious, that there is no increase of produce, of (ither wheat or harley, over the later years, at all commensurate with the increased accumulation of manure in the soil.

You will doubtless be interested to know something of the after effects of these great accumulations of dung in the soil, sceing that they increase the crops so inadequately during the period of the application of the manure.

Table IV. affords some information on this point. The two upper divisions relate to barley, and the lower one to meadow hay. After 14 tons of farmyard manure had been applied for 20 years in succession on one plot in the field devoted to the continuous growth of barley, the plot was divided. On onelalf the annual applicatiou of the dung has been continued, now for a period of 7 years more; whilst the other half has been left unmanured, also now for 7 years. In the experi- 
meuts on meadow hay, the application of 14 tons of farmyard manure per acre per annum was continued for 8 years; and the land lus since been left unmanured for 15 years. The Table shows the produce of barley, corn and straw, and of hay, during the periods of the application of the dung, and after the cessation of the application. It also shows the increase over the continuously unmanured produce over the respective periods.

TALLE IV.

SHOWING THE EFFECTS OF THE UNEXHAUSTED RESIDUE OF FARMIYARD MLANURE.

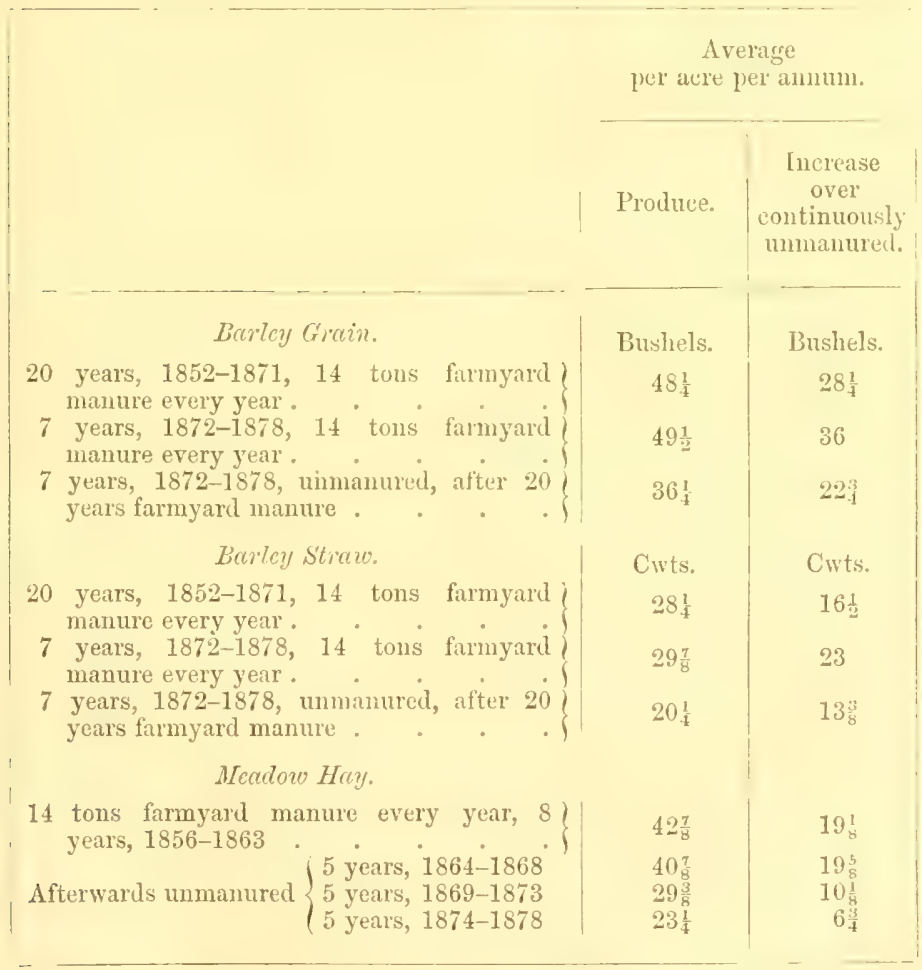

It will be seen that there is an average of only $1 \frac{1}{4}$ bushel of barley grain and $1 \frac{3}{4}$ cwts. of straw, per acre per annum, more over the last 7 years than over the first 20 years, where 
the application of the dung was continued. Where the dung was discontinued after 20 years, the produce of corn was, over the next 7 years, not quite three-fourths as much, and that of the straw but little over two-thirds as much, as where it was continued. The average annunl deficiency was $13 \frac{1}{4}$ bushels of corn, and $9 \frac{1}{2}$ cwts. of straw. Compared with the continuously unmanured produce over the same periods (which, however, declined considerably over the later years) it is seen that the amnually applied dung gave an average increase, over the first 20 years of $28 \frac{1}{4}$ bushels of corn and $16 \frac{1}{2}$ ewts. of straw, and over the last 7 years of 36 bushels of corn and 23 cwts. of straw. And where the dung was discontinued over the last 7 years, there was an average increase of nearly 23 bushels of grain and $13 \frac{1}{2}$ cwts. of straw over the continuously unmanured produce. In the last year of the seven, 1878 , the plot where the application of dung was continued gave $36 \frac{1}{4}$ bushels of corn and nearly $26 \frac{1}{2}$ cwts. of straw more than the ummanured plot; and the plot where the dung was discontinued gave, in the same or seventh year of the discontinuance, nearly 12 bushels of corn, and nearly $10 \frac{1}{4} \mathrm{cwts}$ of straw, more than the unmanured. It is obvious, therefore, that the residue of the 20 years application of dung is still yielding increase. It is, however, gradually declining. But there is no doubt that the residue will continue to be effective in a still more declining ratio for many years to come. It would, indeed, take considerably more than a century at the present rate to recover in increase of produce all the nitrogen of the manure which has not yet been so recovered.

Turning now to the results obtained with meadow-hay, as already stated, 14 tons of farmyard manure were applied per acre annually for 8 years in succession, and the produce has since been taken for 15 years without manure. The Table shows the average anmual produce and increase of hay over the 8 years of the application, and over the first 5 , the second 5 , and the third 5 years afterwards. It will be observed that over the 8 years of the application the average produce of hay was nearly 2 tons 3 cwts. ; and the average increase over the continuously unmanured produce was not quite 1 ton. Over the first 5 years after the cessition of the application, the average produce was about 2 cwts. less; but, substantially, 
both produce and increase averaged much about the same as over the 8 years of the application. Orer the second 5 years, the produce diminished to less than three-fourths as much as over the first 5 , and the increase was little over 10 cwts. of hay per acre per annum. During the last 5 of the 15 years, the produce was little more than half as much as its original amount, and the increase over the mmanured produce of the same period was not quite $7 \mathrm{cwts}$.

During the 8 years of the application of the dung there were obtained, in all, 17 tons $3 \mathrm{cwts}$. of hay, corresponding to 7 tons 13 cwts. of increase; over the next 15 years there were cobtained 23 tons $7 \frac{1}{2} \mathrm{ewts}$, correspouding to 9 tons $2 \frac{1}{2} \mathrm{ewts.} \mathrm{of}$ increase, due to the residue of the previously applied dung. Here, as in the case of the barley, it would require very many years to recover anything like the whole of the yet umrecovered residue of the previously applied nitrogen of the farmyard manure.

Looking to such results as the above, relating to barley and to meadow hay, it is not difficult to understand why a tenant who has been farming lighly for a number of years should endeavour to get out some of the residue of the manure which he has accumulated in the land before he leaves it. But if so small a proportion of the constituents of the manure is recovered in the increase of crop during the years of the application when dung is very liberally used, it is not so evident that higher farming, which means more dung, should be a remedy for lower prices. Nor can I understand why the socalled "lasting" effects of lung should be considered such a merit. The Rothamsted experiments with various crops agree in showing, that a given amount of constituents supplied in dung does less work, and takes a longer time to do it, than when supplied in any other form.

\section{Experiments with Artificial Manures.}

The next illustrations will show the comparative effects of moderate and of large amounts of artificial manures. In the upper division of Table $\mathrm{V}$. we have the average produce of wheat, both corn and straw, over 27 years-by a complex mineral manure used alone; by the same mineral manure and 
200 lus. ammonia salts; by the same and 400 llos.; and by the same and $600 \mathrm{lbs}$. ammonia salts. In the lower division of the Table is given the average produce of barley over 6 years-with supherphosphate of lime alone; with superphosphate and 200 lbs.; and with superphosphate and 400 lbs. ammonia salts.

\section{TABLE $T$.}

SHOWIXG THE EFFECTS OF MODERATE AND OF LARGE AMOUNTS OF AMMONIA SALTS.

\begin{tabular}{|c|c|c|}
\hline & \multicolumn{2}{|c|}{$\begin{array}{c}\text { Average per acre } \\
\text { per annum. }\end{array}$} \\
\hline & $\begin{array}{c}\text { Dressed } \\
\text { Corn. }\end{array}$ & Straw. \\
\hline $\begin{array}{l}\text { Wheat every year, } 27 \text { yecrs, } 1852-1878 \text {. } \\
\text { Complex mineral manure, alone, } \\
\text { Complex mineral manure, and } 200 \text { lbs. ammonia-salts, } \\
\text { Complex mineral manure, and } 400 \mathrm{lbs} \text { ammonia-salts, } \\
\text { Complex mineral manure, and } 600 \mathrm{lbs} \text { ammonia-salts, } \\
\text { Barley every year, } 6 \text { years, } 1852-18 \mathrm{jt} \text {. }\end{array}$ & $\begin{array}{c}\text { Bushels. } \\
15 \frac{3}{4} \\
24 \frac{1}{2} \\
33 \frac{1}{3} \\
36 \frac{3}{4}\end{array}$ & $\begin{array}{r}\text { Cwts. } \\
13 \frac{1}{2} \\
22_{4}^{3} \\
33_{\frac{3}{4}}^{\frac{3}{4}} \\
40 \frac{3}{8}\end{array}$ \\
\hline $\begin{array}{l}\text { Superphosphate, alone, } \\
\text { Superphosphate, and } 200 \mathrm{lbs} \text {. ammonia-salts, : } \\
\text { Superphosphate, and } 400 \mathrm{lbs} \text {. ammonia-salts, : }\end{array}$ & $\begin{array}{l}31 \frac{5}{8} \\
45 \frac{1}{2} \\
49 \frac{5}{6}\end{array}$ & $\begin{array}{l}16 \frac{1}{2} \\
28 \frac{3}{8} \\
34\end{array}$ \\
\hline
\end{tabular}

Tieferring first to the wheat, it will be observed that by the addition of $200 \mathrm{lbs}$. of ammonia-salts per acre per annum to the mineral manure, an average increase of nearly 9 bushels of grain is obtained. By the addition of a second $200 \mathrm{lbs}$, in all $400 \mathrm{lbs}$. of ammonia-salts, there is a further increase of the same amount, that is, nearly 9 bushels. By the addition of a third 200 lbs., in all $600 \mathrm{lbs}$. of ammonia-salts, there is a further increase of only $3 \frac{1}{2}$, instead of 9 bushels. In like manner the first $200 \mathrm{lbs}$. of ammonia-salts give $9 \frac{1}{4}$, the second 11 , and the third only about $6 \frac{1}{2}$ cwts. increase of straw. Now,

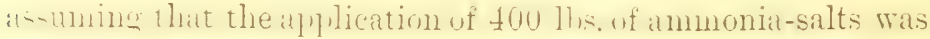
the limit of high farming with profit with wheat at $6 \mathrm{~s}$. per bushel, I cannot see how it could be muintained that a further 
200 lbs, rieleling little more than at third at much increase at when used in more moderate quantity, should be employed because the price of wheat was reduced to こ̌s. per bushel. On the contrary, the conclusion I should draw from the results of these experiments is, that the application of the boo lhs. of ammonia-salts could only be profitable if the price of whent were to rise instead of to fall.

Again, it will be seen that in the case of the barley, the aldition to superphosphate of lime, of 200 lhs. of anmoniasalts gave an average increase of nearly 14 lushels, whilst by the addition of a second $20011 \mathrm{~s}$, in all $40011 \leq$ of anmonialsalts, a further increase of little more than 4 bushels was obtained. It will be observed, however, that whilst with the increase of 14 bushels of grain there was an increase of only $12 \mathrm{cwts}$. of straw, there was with the further increase of 4 bushels of grain an increase of $5 \frac{1}{2}$ crrts. of straw, or a much linger proportion of straw to corn in the increase by the secomi than in that by the first 200 lbs. of ammonia-salts. It was, in fact, so evident from the bulk, and the laying of the crop, that 400 lbs. of ammonia-salts was an excessive application, that, after its use for 6 years, the experiment wats alnudoned. Here, again, I think it must he erilent that it would be higher', and not lower prices, that would justify the higher stamlard of farming.

From the various results which I have laid before you, you will have gathered that when farmyard manure is used, and even, though in a less degree, when manure is deposited on the land by animals feeding upon it, there is less immediate increase for a given amount of constituents supplied, ant more accumulation within the soil, than when certain artificial manures are employed. You must not suppose that, in bringing this fact prominently to your notice, I wish in any degree to depreciate the imprortance of, so to speak, naturil manures, and to exalt that of artificial manures. The production, and the use, of farmyard manure, are a necessity of the general economy of a farm; and there must be the more of it produced, or at any rate the more of animil manures, the greater the amount of meat produced. Nor would it be possible to rely mainly on artificial manures. I do think, 
huwever, that farmers generally do not sufficiently recognise the slowness of the action of the natural manures of the farm; and that, so far as they do so, they frequently even look upon it as a merit rather than otherwise, that it should be as they say, more "lasting." But slowness of action means slowness of return for the outlay; and this will be the greater the more excessive the amount of the manure applied. In my opinion, the object to be attained, and that which I have no doubt will characterise the most successful farming of the future, is to get as quick a return as possible for the outlay in manures, whether natural or artificial. This can only be fully accomplished-with freedom in the growth and sale of that produce which is the most profitable, the selection of the crops which are the most suitable to the soils and seasons of the locality and the demands of the market, and such a judicious adaptation of natural and artificial manures to the crops to be grown, as to obtain the maximum incrense of produce, with the minimum residue left unproductive in the soil, and subject to loss by drainage, and in other ways.

To sum up in regard to this first branch of my subject:- It has been shown by reference to the results of experiments on an ordinary four-course rotation with different manures, in some cases carting off the roots, and in others consuming them on the land, that, beyond a certain limit, the increase of produce was not commensurate with the increase in the amount of manure accumulated within the soil. The next illustrations showed that, when farmyard manure was used in excessive amount, for the direct growth of either wheat or barley, the increase of produce by no means corresponded with the accumulation of manurial constituents within the soil; that, notwithstanding an increasing accumulation from year to year, the crops even diminished in the later years under the influence of bad seasons, the increased amount of manure in the soil not fully compensating for the adverse influences of the seasons; and lastly, that the unexhausted residue of the previously applied dung, though yielding a considerable increase for many years afterwards, dic so in a rapidly decreasing ratio, and only in such proportion that it would take very many years to recover the manme applied; even if, which cannot be supposed, it were ever fully recovered. In like 
manner it has been shown, that when artificial nitrogenous manures were used in gradually increasing amounts, the amount of increase obtained for a given amount of manure employed, very greatly diminished when the quantity applied exceeded a certain limit, which may he called the standard of high farming; so that, a given quantity of further increase was obtained only at a greatly increased proportional cost for manure.

The general and uniform result of the whole is, that, whether we go from high to still higher farming with an ordinary rotation of crops, with large amounts of farmyar manure applied year after year for the growth of corn, or with artificial manures in gradually increasing amounts, less increase of procluce is obtained for a given amount of manure applied, the greater the excess of it over what may be termed the standard of moderate high farming. I leave you to judge whether, under such circumstances, the advance from high to still higher farming is likely to compensate you for lower prices of your produce.

\section{The Manure produced by the Animals of the Farm.}

I now come to the second branch of my subject, namely, the cost of the manure produced upon the farm. It may perhaps he assumed that, in the case of the horses working upon the farm, their labour may be taken as an erfuivalent for the cost of their food, the expenses of attendance, \&c., and that the manure they produce is, so far, obtained free of cost. In the case of the feeding of animals for the prodnction of meat, store stock may be cheap and fat stock dear, or vice versa, cattle food may be cheap and meat dear, and so on. In considering therefore whether, as a rule, the value of the meat produced is more or less than the cost of the food of the amimal, together with the other expenses, it will be necessary to exclute from the calculation all such exceptional cases as above referred to; to take as the basis of any conclusions (so far as we can estimate it) only the average amount of food required to produce a given weight of increase; and to compare the cost of such food, and other expenses, with the value of the increase. Looking at the subject from this point of riew, I think it will be found that the outlay is generally 
much in excess of the receipts; and that there is, therefore, a balance left over which must be reckoned as the cost of the manure.

Confining my attention to cattle, I shall first endeavour to show, by reference to published records relating to animals of certainly above average quality, and undoubtedly liberally fed, what is the probable rate of increase that may be expected in such cases; and secondly, what is the average amount of food required to produce a given amount of increase.

In Table VI. are given, the ages, weights, and increasefirst, of a number of prize cattle exhibited at Smithfield, in December 1878, as recorded in the Agricultural Gazette of Jamuary 13,1879 ; secondly, of a number of prize cattle exhibited at the Chicago Society's Show (United States), and reported in the Country Gentleman's Newspaper; thirdly, of some French cattle of the Nivernais-Charolais breed, the particulars of which will be found in the Journal of the Royal Agricultural Socicty of England, vol. xv. p. 213 ; lastly, at the foot of the Table is given, for comparison, the estimate of the average rate of increase during the fattening period, as adopted at Rothamsted many years ago.

\section{TABLE VI.}

Ages, Weights, and Increase of Cattle.

\begin{tabular}{|c|c|c|c|c|c|c|}
\hline \multicolumn{3}{|c|}{ Description. } & \multirow{2}{*}{$\begin{array}{c}\text { Average } \\
\text { Age. }\end{array}$} & \multirow{2}{*}{$\begin{array}{c}\text { Average } \\
\text { Final } \\
\text { Weight } \\
\text { per head. }\end{array}$} & \multirow{2}{*}{$\begin{array}{c}\text { Increase } \\
\text { per } \\
\text { Day. }\end{array}$} & \multirow{2}{*}{$\begin{array}{l}\text { Increase } \\
\text { per } \\
1000 \mathrm{lbs} . \\
\text { Live- } \\
\text { weight } \\
\text { per } \\
\text { Week. }\end{array}$} \\
\hline & $\begin{array}{c}\text { No. } \\
\text { of } \\
\text { Class. }\end{array}$ & $\begin{array}{l}\text { No. } \\
\text { in } \\
\text { Class. }\end{array}$ & & & & \\
\hline \multirow[t]{2}{*}{$\begin{array}{l}\text { Prize Caltie at Smith- } \\
\text { ficld, } 1878 .\end{array}$} & \multirow{2}{*}{\multicolumn{2}{|c|}{\begin{tabular}{r|r}
1 & 9 \\
2 & 7 \\
3 & 5 \\
4 & 3 \\
& \\
\multicolumn{2}{r}{ Average, }
\end{tabular}}} & $\begin{array}{r}\text { Week } \\
116 \\
167 \\
215 \\
165\end{array}$ & $\begin{array}{l}\text { lbs. } \\
1301 \\
1568 \\
1785 \\
1456\end{array}$ & $\begin{array}{l}\text { lbs. } \\
1.60 \\
1.34 \\
1 \cdot 19 \\
1 \cdot 26\end{array}$ & $\begin{array}{l}\text { lbs. } \\
14 \cdot 8 \\
10 \cdot 5 \\
8 \cdot 3 \\
10 \cdot 6\end{array}$ \\
\hline & & & $165 \frac{3}{4}$ & $1527 \frac{1}{2}$ & $1 \cdot 35$ & $11 \cdot 1$ \\
\hline
\end{tabular}




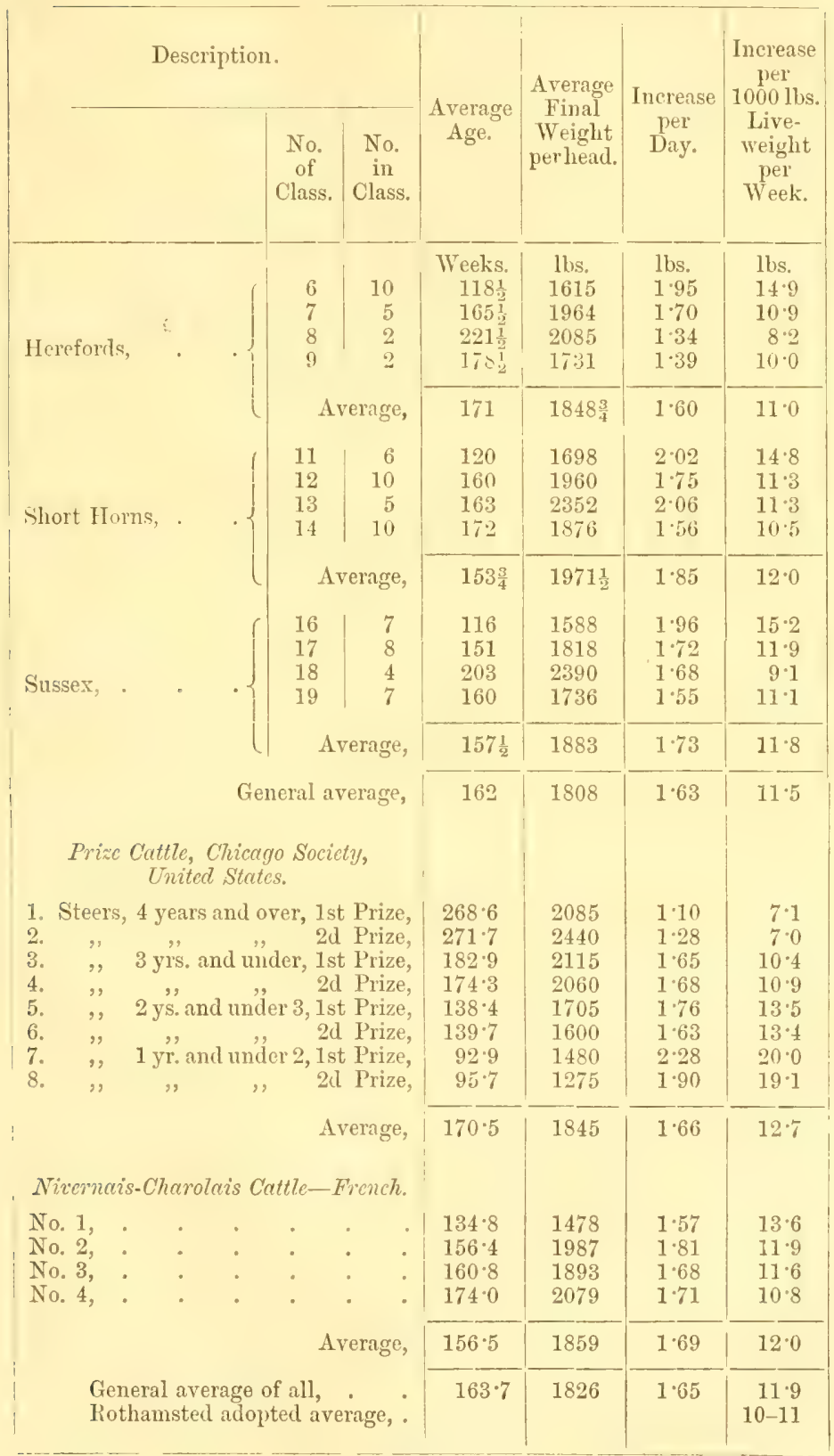


Before discussing the figures given in the Table, it will be well to give some explanation of how they are obtained. The ares, and the final weight per head, are the actual data recorded. The increase per day is obtained by dividing the final weight by the number of days of age. This is the mode of representation adopted in the United States; and the figures given in this column for the Chicago cattle are those actually recorded; whilst those for the Smithfield and French cattle are calculated as above described. It is obvious that such a mode of reckoning, however valuable it may be in comparing the rates of increase of animals of the same lescription, oxen, for example, but of different hreeds, or of different ages, it is quite inapplicable in comparing the rates of increase of animals of different descriptions, and of different sizes; of oxen, sheep, and pigs, with one another, for example. Many years ago, when considering this subject, we felt the necessity of adopting some mode of representation which enabled us to compare the amounts of fiod consumed, and the anomits of increase produced, not only among animals of the same, but of different descriptions, and of all sizes. Accordingly, the standards we adopted were:-

The amount of food consumed per 100 lbs. live-weight per week.

The amount of food required to produce $100 \mathrm{lbs}$. increase in Iive-weight.

The increase per $100 \mathrm{lbs}$. live-weight per week.

But as, on the present occasion, I am dealing with cattle only, I give, as you will see in the last column of the Table, the increase per 1000 lbs. live-weight per week. At the foot of this last column is given the average increase per $1000 \mathrm{lbs}$. live-weight per week of all the cases recorded in the Table, including the different breeds of the different countries; "babies" of two years old and under, and mature animals of four years old and over. This general average of such very varied individual cases shows 11.9 , or nearly $12 \mathrm{lbs}$. increase per 1000 lbs. live-weight per week, whilst the Rothamsted extimate, arlopited many years ago, is 10 to $11 \mathrm{lhs}$. per $1000 \mathrm{lbs}$. live-weight per week, as the average rate of increase of oxen during the last few months of feeding on good fattening food. To en a little more into detuil, compared with this Rothamsterl estimate of 10 to $11 \mathrm{lbs}$, the average of the different lots of the 
Simithield prize cattle gives $11.5 \mathrm{ll}$ s., that of all the Chicaso cattle 12.7 lbs., and that of the four French cattle 12 los.

In making these comparisons it must be borne in mind, however, that whilst in the case of the Smithfield, Chicago, and French cattle, the increase is, for want of other data, calculated upon the average live-weight from birth to final weight, in that of the Rothamsted estimates it is taken nuon the average weight of the final fattening period only; and as the rate of gross increase upon a given live-weight within a given time is considerably higher in the earlier than in the later periods of the life of the fattening animal, the figures are, so far, not strictly comparable.

On the other hand, a mature animal contains a larger proportion of saleable carcass, and a less proportion of internal organs, and offal generally, than a young or store one. The mature animal also contains a much higher percentage of clry or solid substance, and, accordingly, a lower percentage of water. These differences are clearly illustrated in the following Table, which gives the proportion of carcass in 100 fasten live-weight, and also the percentages of dry or solid substance, and of water, in 10 animals of different deseriptions, and in different conditions as to age and fatness, which were analysed at Rothamsted, now nearly thirty years ago.

\section{TABLE VII.}

COMPOSITION OF VARIOUS ANIMALS.

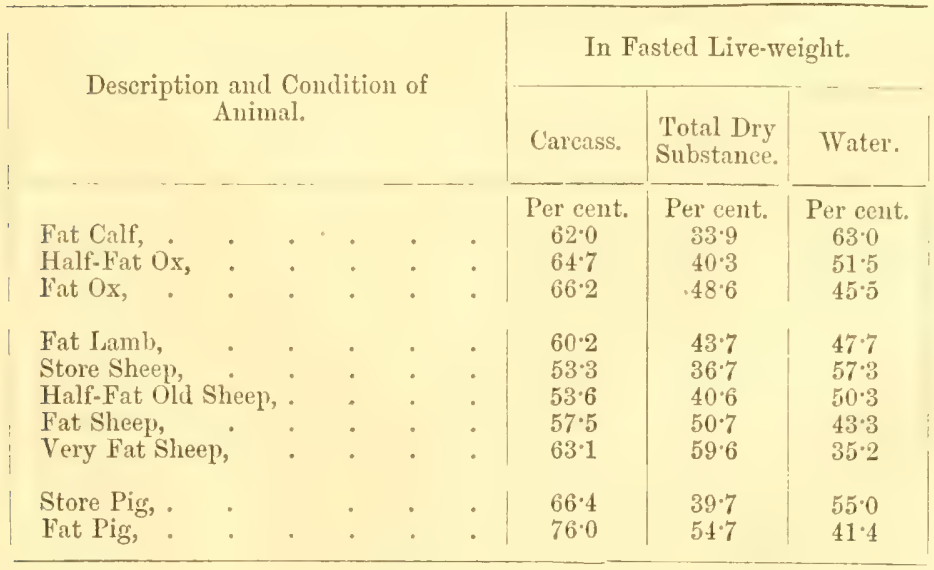


Thus, you will see that even a fat calf contained a much higher percentage of water, and lower percentage of solid matter, than a half-fat ox; whilst the fat ox contained much more dry or solid matter than the half-fat one. Then, again, anoug the sheep there is a gratually inereasing percentage of dry or solid matter, and decreasing percentage of water, from the store to the half-fat, from the half-fat to the fat, and from the fat to the very fat condition. A similiar result is observed as between the store and the fat pig. From these facts you will see that, although the gross increase is less in proportion to the live-weight as the animal matures, a larger proportion of such gross increase consists of carcass, and of real solid matter, and a less proportion of offal, and of water. In fact, the fattening process may be said to consist in great measure in the displacement of water by fat.

Accepting the figures given in Table VI. as giving a fair idea of the rate of increase of well-bred and well-fed animals, the question arises-at what cost of food has that increase been obtained? We have no records on this point in regard to any of the animals referred to in the Table. We must, therefore, rely upon other data in arriving at a decision on this part of the subject. Our own estimate, founded on all the data at our command, partly relating to the recorded experience of others, and partly to the results of direct experiments of our own, led us many years ago to conclude as follows:-

"Fattening oxen, liberally fed upon good food, composed of a moderate proportion of cake or corn, some hay or straw chaff, with roots or other succulent food, and well managed, will, on the average, consume 12 to 13 lbs. of the dry substance of such mixed food, per 100 lbs. live-weight, per week; and they should give $1 \mathrm{lb}$. of increase for 12 to $13 \mathrm{lbs}$. dry substance so consumed."

In other words, there will be consumed from 120 to 130 lbs. of the dry substance of such mixed food per 1000 lbs. liveweight per week, producing on the average 10 lbs. of increase ; and 1200 to $1300 \mathrm{lbs}$. will, therefore, be required to yield 100 lbs. increase in live-weight. If the mixed food contain no straw-chaff, and only a moderate amount of hay-chaff, the average amount of dry substance consumed will be the less, and the average proportion of increase the more, or vice verse. 
Accordingly, we have assumed that on a liberal mixture of oilcake, clover-chaff, and swedes, as little as 1100 lbs. dry substance may be required to produce 100 llus. increase, and as much as 11 lbs. increase may be produced per $1000 \mathrm{lbs}$. live-weight per week.

The articles which you are accustomed to speak of as dry foods, still contain some water. Thus, cakes contain from one-eighth to one-nintl, and corn, hay, and straw, about onesixth of their weight of water ; whilst swedes do not contain more than 10 to 12 , or mangolds more than 12 to 13 per cent. of really dry or solid matter; but the monster roots of which we hear so much, sometimes contain only about twothirds as much dry matter as moderately sized and wellmatured roots should do. Of really dry substance, such as my estimates given above require, 1200 to $1300 \mathrm{ll}$ is., say 1250 lbs., would, in round numbers, be supplied in the following amounts of each of the several descriptions of food enumerated, supposing them to be of fair average composition in that respect.

\section{TABLE VIII.}

AMOUNT OF EACH FOOD CONTAINING 1250 LBS. DRY MATTER.

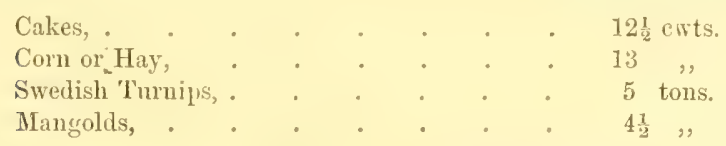

The question arises-What would be the cost of $1250 \mathrm{lbs}$. of dry substance, made up of a suitable mixture of these various foods, to yield $100 \mathrm{lbs}$. increase in live weight, and whether this would be less or more than the $100 \mathrm{lbs}$. increase would sell for?

Well-bred and moderately fattened oxen should yield 58 to 60 per cent. carcass in fasted live-weight; very fat oxen may yield from 65 to 70 per cent. But of the increase obtained iuring what may be called the fattening period of moderately fattened oxen, it may be reckoned that about 70 per cent. will be earcass. Supposing you get 8d. per lb. for this, the selling value of your $100 \mathrm{lbs}$. increase in live-weight will be $46 \mathrm{~s}$. $8 \mathrm{sl}$. Now, I think if you try to make up $1250 \mathrm{lbs}$. of dry substance 
by a suitable fattening mixture of the foregoing foods, you will find that it will cost you considerably more than $46 \mathrm{~s}$. $8 \mathrm{~d}$. Even if roots alone were used, which would not be considered good fattening food, the cost would be more if they were reckoned at their selling price, though less if taken at what is called their "consuming value." But with no good fattening mixture of cake or corn, hay-chaff, and roots, could 1250 lbs. of dry matter be obtained for anything approaching the sum I have estimated as the value of the increase it will produce.

It is further to be borne in mind that, weight for weight, store stock is generally dearer than fat stock. You have also to add to the cost of the food various other charges, such as pent of builhings, appliances, attendance, and risk. Taking all these things into account, I think it is evident that there must always be a very considerable proportion of the cost of feeding, although varying greatly according to circumstances, which must be taken to represent the cost of the manure.

In 1876, the Council of the Ioyal Agricultural Society of Fingland appointed a committee to consider the question of the valuation of unexhausted manures, with reference to the provisions of the Agricultural Holdings Act; and a Table of the estimated value of the manure obtained by the consumption of different articles of food, which I had first published about 16 years previously, and after reconsideration rejublished more recently, was much discussed and criticised. The general impression arrived at was, I think, that my estimates of manurevalue were too high. Accordingly, Dr Gilbert and I selected linseed cake as the best known article of purchased cattlefood, and, after deducting my estimate of the manure-value from the cost of the cake, we endeavoured to calculate whether the remainder of the cost could be recovered in the increased value of the animal. The best linseed cake was then quoted at $£ 12,10$ s. per ton, and deducting the manure-value as given in my Table, namely, $\mathfrak{L} 4,12 \mathrm{~s}$. 6 d., there was left $\mathfrak{E} 7,17 \mathrm{~s} .6 \mathrm{~d}$. to be charged against the animal, and calculation led us to the conclusion that it was extrenely doult ful whether this amount could be recovered in its increased value. In fact, linseed cake appeared to us to command what may be called a fancy price. At any rate, it was quite certain that it could not be 
profitably used, if not fully as much, or even more, than the amount of my estimate. were charged against the manure.

Although in the foregoing illustrations I have confined my attention to oxen, if the same mode of calculation were applied to sheep and to pios, it would be found in their case also that the cost of their food is more than the value of the increase it produces. Notwithstanding that the contrary view is so frequently assumed, the use of the term "consuming value," as distinguished from selling price, seems to reconnise that food stuff's have a value other than as food alone. If restrictions upon the sale of roots, hay, and straw, were abolished, these articles would soon cease to have what may he called a fancy luice; and the diflerence hetween the so-callerl "consuming value," and the real selling price, would more nearly represent the value of the manure.

In the former part of my address, I have shown that, beyond a certain limit, the increase of crop does not keep pace with the increase in the amount of manure applied to the laud, and that this is esprecially the case in atrancing from high to still ligher farming: I have now adduced evidence which must, I think, convince you that the manmes of the farin cost money. It seems to me that an obvious deduction from these two facts is, that to apply manure in such quantity as to obtain a diminished produce for a given amount of it can only be profitable when the price of the produce rises, and not when it falls. So far, however, as increased production is to be attained by the exercise of frextom, intelligence, and economy, in management, so as to get the maximum amount and value of produce from the manure that is applied to the land, and the maximum amount and value of meat and manure for the outlay in store-stock and in food, increased production is a necessity of the times, and would prove the best remedy for lower prices of farm produce.

I regret to find that the opinions I hold, and have rentured to express to you, are not in accordance with those of many who write upon the condition of the farming interest at the present time. Nor do they quite accord with the advice given to you in this room, by Lord l'olwarth, only in February last. In a letter which his lordship subsequently published, in 
further explanation of his views, he said that, for increased production, "greater liberty in cultivation is desirable;" and again, that, "there must be increased capital, scope for enterprise, and security of tenure." In this I entirely agree, excepting that I would venture to say that such changes are not. only "desirable" but essential.

To attempt to meet falling prices by increased production upon the old lines, that is, by simply increasing the amount of manure brought upon the land, and at the same time maintaining the old rules and restrictions as to cropping and sales, would, in my opinion, be entirely futile. If all restrictions were abolisherl, excepting such as would secure that the tenant should give up his farm in as good a state as he entered upon it, the position of things would be entirely changed, and some of my remarks would then require molification accordingly.

Recent discussions clearly show that landowners fully recognise the gravity of the present state of affairs, and that they are desirous of assisting the tenant by the relaxation of existing covenants, and in other ways. In addressing tenantfarmers, I would venture to ask-whether, on their side, this is not a favourable opportunity for taking stock of the modes in which they conduct their business, with the view of bringing their operations more into accord with the rules which regulate other commercial undertakings?

In illustration of my meaning, I will call attention to the way in which the business connected with the stock of the furm is generally conducted. Farmers are justly proud of their fine animals, and consider them to be the back-bone of British agriculture. But is it not a fact that every transaction in this immense branch of industry is carried on almost exclusively by guess-work? Neither in purchasing store-stock, nor in selling fat stock, are the scales brought into requisition. Again, in the feeding operations, neither the amount of increase produced, the amount and the cost of the food required to produce it, nor the comparative value of different foods in regard to their feeding and manure productireness, are taken into calculation.

Of late, store-stock have been very dear, and I have little doubt that, if tested by the scales, it would be found that oxen and sheep have been bought at prices which would 
represent 6d. per 1b. Now, 6d, per $1 b$. is $£ 56$ per ton. To purchase 10 tons of store-stock would not be a very large purchase to make. Now, I should like to ask the best judges of stock in this room to pick out from a herd of oxen, or a flock of sheep, as many as they thought would make up 10 tons in weight; or to see, if two or three went to work independently, how nearly their estimates would agree! If your coal-merchant, or your manure-dealer, proposed to sell you those commodities by the heap, you would not hear of such a thing, and you would insist upon purchasing by weight. But, weight for weight, these articles bear no comparison in value with that of animals. If, then, with articles of comparatively little value you will not buy by the lump, regardless of exact weight, why should you do so with anything so costly as your store-stock? I admit that I am myself compelled to adopt the custom of the trade; but I nevertheless thoroughly resent it, and feel that I never know whether my purchase has been a gooul or a bad one, until I have bronght the animals to the scales, and calculated the price per pound of live-weight. The eye is the proper judge of quality, and the price per pound, or per ewt., should be settled accordingly; and, this done, the total value should be settled by the scales.

The same plan of guessing is adopted in the sale of the fat stock. Here the butcher is sure to have the best of the hargain; for every day his gnesses are checked by reference to the scales, whilst the farmers are not, and what chance has the feeder, or his salesman, against such an advantage as this?

If the farmers of the country at large were to agree to declare that they would only buy and sell stock by weight, they would doulthless have ample power to enforce their decision.

The same indifference to weights is manifested throughout, from the birth of the animal until it reaches the butcher. There is the clearest evidence of this in the discussions of the sulnject amongst farmers themselves, whether at home, at the market table, or at the clubs. If the custom of buying and selling stock by weight were once established, and it is so already to a great extent in America, the advantages to the farmer would be very great in various ways. He would not only be able to test the money result of his actual purchases 
and sales, but he would gain much experience, which would sharpen his judgment in the matter in the future. A greater advantage still would be, that he would be led to test his practice at every intermediate stage between the breeding or the buying and the selling. He would ascertain what were the best mixtures of food to use, according to the seasons and to the markets. He would determine-whether his animals were giving a proper rate of increase; how inuch of different foods they required to produce it; and he would carefully consider also the manure-value of the different foods. $\mathrm{He}$ would, in short, take the only means of insuring economy in his meat and manure manufacture.

I was asked by your Secretary to address you this evening on the most economical method of producing meat. But I felt that, as the only way in which I could properly treat the subject would be by reference to weights, both of the food and of the animals, it would be, to many, neither interesting nor instructive; it would, in fact, be like speaking in an unknown tongue.

I will endeavour to illustrate my meaning by reference to a question which is much discussed at the present timenamely, the relative economy of producing young or old beef.

If you look at Table VI., to which I have already called attention, you will find that in the top line of each of the four divisions, relating, respectively, to the four English breeds, you have an example of early maturity; and the increase per day, and the calculated increase per 1000 lbs. live-weight per week, show, by comparison with the older animals, a more favourable rate of increase. To produce the same weight in two years as would otherwise be only attained in three years or more, is, of course, in many points of view, a great gain. As animals consume and expend a given amount of food ditily, in proportion to their weight, merely in the maintenance of their existence, it is obvious that there is, so far, a considerable saving of food if the same weight is attained in one-half or two-thirds the time. Other expenses will also be more or less reduced the shorter the time required to produce a given weight. It is true that, so long as an animal only feeds in a pasture in the summer, and only receives straw and roots in 
the winter, it lives at comparatively little cost, even if it make but slow progress, until the final period of fattening begins. Again, as the animal matures, it consumes less food for a given live-wreight within a given time, a given weight of food gives rather less gross increase, but a given weight of gross increase represents more carcass, more solid matter, and less water. On the other hand, to obtain the more rapid increase, much more costly food must be given throughout the life of the animal.

It is obvious that the two systems cannot be fairly compared, without taking into the calculation aceurate data-as to the cost of attendance, the quality, quantity, and cost of the food consumed, the rate and value of the increase, and the value of the manure in the two cases. Yet in none of the discussions of the subject of which I have seen the records has there been any attempt to bring figures relating to these various points to bear upon the question.

A few weeks ago there was an article in the North British Agriculturist headed "Young $v$. Old Beef." The Elitor justly speaks of the excellence of the article, which he says was written hy a well-known shorthorn breeder, who has oftener than once tasted the sweets of first honours at the Smithfield and other National Fat Shows. The writer gives the increase of weight of five cattle, of different ages, from March 1 to November 1 . He says, that the animals were fed on the best he could procure for them, were all healthy during the experiment, and all figured as first prize takers at Christmas Shows. But, he alds, the food was not weighed; and further on he says, " this instance I have selected from many in my note books of live-weights of animals, and increase at lifferent times; and the proportionate increase of weight of different aged animals is fairly stated in the above examples."

I gather from these statements that it is assumed by the writer that the rates of increase quoted are what may be expected in the case of first-class shorthorns of the ages given, and fed upon the best food that can be procured for them. They were as follows; and I have atded a column showing the rate of increase per head per week, obtained by dividing the total increase by 35 , the number of weeks from March 1 to November 1:- 


\begin{tabular}{|c|c|c|}
\hline & \multicolumn{2}{|c|}{ Increase in Live-weight. } \\
\hline & $\begin{array}{l}\text { From Mareh } 1 \\
\text { to } \\
\text { November } 1 .\end{array}$ & $\begin{array}{l}\text { Per head per } \\
\text { week. }\end{array}$ \\
\hline $\begin{array}{l}1 \text { Four-year-old, } \\
1 \text { Three-year-old, } \\
3 \text { Two-year-olds (avernge per head), }\end{array}$ & $\begin{array}{l}\text { Cwts. } \\
\begin{array}{|ccc}1 & \text { qrs. } & \text { lbs. } \\
1 & 2 & 0 \\
2 & 0 & 0 \\
4 & 0 & 24\end{array}\end{array}$ & $\begin{array}{r}1 \mathrm{bs} . \\
4 \frac{3}{4} \\
6 \frac{1}{2} \\
13 \frac{1}{2}\end{array}$ \\
\hline
\end{tabular}

The actual weights of the animals are not given. But it may be assumed that the four-yent-old ox would weigh nearer 2000 lbs. than 1000 lbs.; so that the rate of increase would probably not be more than $2 \frac{1}{2}$ or 3 lbs. per 1000 lbs. liveweight per week, instead of 10 to 11 lbs. according to our estimate. Nor would either of the younger animals show a sufficient rate of increase; though the evidence is certainly very much in favour of the younger animals. The $4 \frac{3}{4} \mathrm{lbs}$. increase per head per week of the four-year-old would be worth about two shillings; and I leave you to judge what relation that sum would bear to the cost of feeding a fouryear-old shorthorn on the best of everything! These figures afford some idea of the cost of obtaining a prize, but they are of no value as examples of profitable feeding.

It must be understood that in making these remarks I do not wish to find any fault with the writer, who is obviously a man of much intelligence and experience. But I wish to enter a protest against the system of disregarding attention to the weights of animals, to their rates of increase, and to the quality, quantity, and cost, of the food they consume to produce it, which alone could render it possible that such results could be quoted as examples of successful feeding.

It is a somewhat humiliating admission to make, though so far it has proved to be too true, that the virgin soils and plains of the United States and Canada can produce, and send to this country, com and meat cheaper than they can be produced on our own soils at home, with all our boasted skill and science. The opinion expressed by some, that we shall again become exporters of corn, is altogether chimerical. But we have at any rate the cost of transit in favour of home production. 
This, though a less considerahle protection in the case of grain, must always be a material item in the case of live animals, and of meat; and the rearing and feeding of stuck must always form an important branch of our farming.

It is such a generally accepted opinion that the agriculture of Great Britain is superior to that of any other country, that you will perhaps be disposed to resent the allegation that there is very much in your practice which requires improvement. During the last thirty or forty years, our knowledge of the productive effects of different manures, of the food require. ments of different animals, of the increase they should yield, and of the value of the manure they produce, has made great progress. But comparatively few British farmers pay any attention to such subjects, or care to avail themselves of the information at their disposal. It is true that much of the existing data is not yet available in a form which would be easily intelligihle to farmers generally, but this is because there is little demand for such knowledge; and a comparison of the current agricultural literature of this country with that of America, and of some parts of the European continent, would show that the demand is greater in those countries. So long, indeed, as the old routine yielded fair profits, what reed was there of any change? But the present crisis, though I fear it may bring loss and suffering to many, will not be without some advantages, if it should lead to the conduct of agricultural operations on a basis more in accordance with both commercial and scientific principles. 



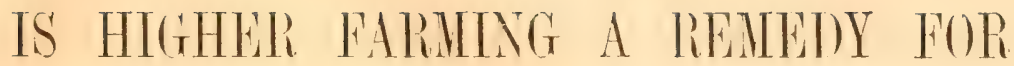

\section{LOWER PRICES !}

IEENG THE SUBSTANCE OF A LECTURE DELIVERED BEFORE THE EAST BERIICKSHIRE AGRICULTURAL ASSOCLATION, ON SATURDAY, MAY, 1879.

ISY

.JOHN BENNET LAWES, LL.I., F.L.S., dE., UF LOTHAMTEW, HERT'

BELWI(K-UPON-IWEED:

PUBLISILE BY G. MACASKIE, "WARDER" OFFICE. 1879. 





LIBRARY OF CONCRESS

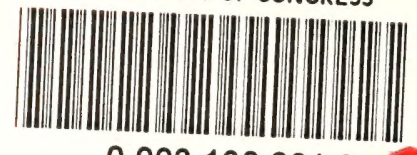

00031386810 